\title{
H22 年 7 月豪雨による厚狭川中流域の 中山間部での洪水汇濫流の分析 INUNDATION FLOW IN MOUNTAINOUS VILLAGE IN ASA RIVER BASIN DURING 2010 JULY TORRENTIAL RAINFALL EVENT
}

\author{
椿 涼太 $^{1} \cdot$ 朝位孝二 $^{2} \cdot$ 中村明彦 $^{3} \cdot$ 戸村健太郎 $^{3} \cdot$ 河原能久 $^{1} \cdot$ 永野博之 $^{4}$ \\ Ryota TSUBAKI, Koji ASAI, Akihiko NAKAMURA, Kentaro TOMURA, Yoshihisa KAWAHARA \\ and Hiroyuki NAGANO \\ 1 広島大学大学院 工学研究科 (广 739-8527 東広島市鏡山 1-4-1) \\ 2 山口大学大学院 理工学研究科 (T 755-8611 山口県宇部市常盤台 2-16-1) \\ 3 アジア航測株式会社 防災地質部 († 215-0004 神奈川県川崎市麻生区万福寺 1-2-2) \\ 4 八千代エンジニヤリング株式会社 名古屋支店 (广 460-0003 名古屋市中区錦 3-10-33 錦 SIS ビル)
}

\begin{abstract}
In this paper, an inundation flow in the Matsugase district, Sanyo-Onoda City, during the 2010 July torrential rainfall event was analyzed. Topographical data of this area were measured by aerial LiDAR survey. The DEM obtained by the LiDAR survey was verified by field survey data measured by RTK-GPS. A shock-capturing shallow water flow model with a fine calculation grid (two to 5 meters in resolution) was utilized to represent inundation flow in the inundated area. The calculated water depth was compared with the water records. The characteristics of inundation flow, especially the effect of the embankments in the inundated area, and those relation to local damage were discussed. Effects of embankment rise and reduction of energy loss due to a bridge were evaluated.
\end{abstract}

Key Words: Inundation, Asa River, mountainous village, railway embankment

\section{1.はじめに}

中山間地域では，河道に沿って家屋，田畑，道路や 鉄道が配置される一方で, 河川整備水準が必ずしも十 分でない場合が多く，水災害に対して相対的に脆弱と いえる。道路や鉄道への被害は，その影響が被災箇所 に限定されず，その交通網に接続した地域社会全体へ 波及する。一方で，このような人口や資産の密度が比 較的低い地域に対して, 大規模降雨まで対応できる水 準までの河川整備を行うことは現実的でなく, 氾濫を 許容しつつ, 氾濫流の特性を踏まえた防災・減災を図 ることが現実的である.

本研究では, 平成 22 年 7 月に発生した厚狭川中流域 の中山間部での洪水汇濫事例を分析する．まず，航空 レーザー測量データを用いて, 中山間地における洪水 氾濫流を, 比較的詳細な計算格子を用いた汇濫解析に より評価する。続いて, 本事例での洪水汇濫流の特性 を分析し, 最後にその特性を踏まえた減災対策の立案 を行う。

\section{2. 被害状況概要}

\section{(1) 流域特性}

図-1に厚狭川の流域図を示す。厚狭川は標高 $534 \mathrm{~m}$

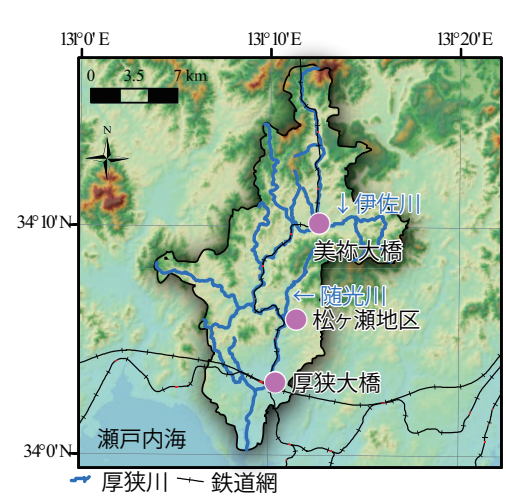

図-1 厚狭川流域

の美祢市於福・大ヶ峠を源流とする流域面積 $245 \mathrm{~km}^{2}$, 流路延長約 $43.9 \mathrm{~km}^{2}$ の河川であり, 山口県が管理する 二級河川である ${ }^{1)}$. ほぼ本川にそって JR 西日本・美祢線 が配置されている. 本研究で対象とする中流域は, 谷底 低地と峡谷部分を流れる区間であり, 河床勾配は $1 / 240$ 程度である。

\section{(2) 降雨特性}

平成 22 年 7 月の降雨は厚狭川流域の中流域に集中し, 10 日から 15 日までの総降水量は, 美祢市東厚保で 588 


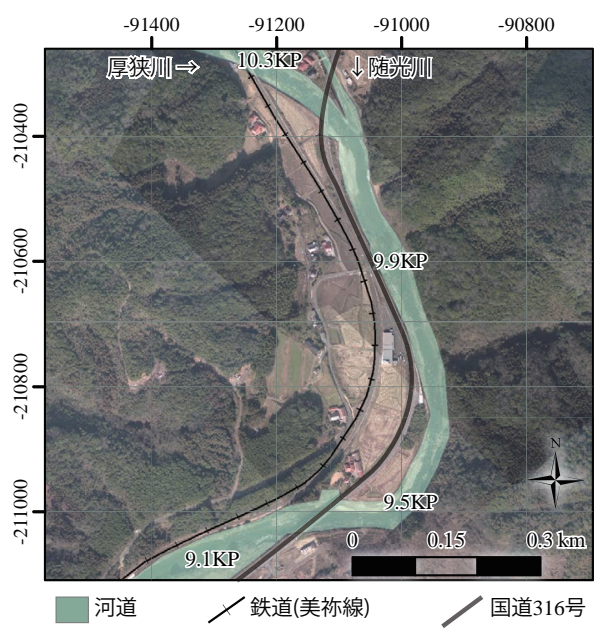

図-2 松ヶ瀬地区の航空写真

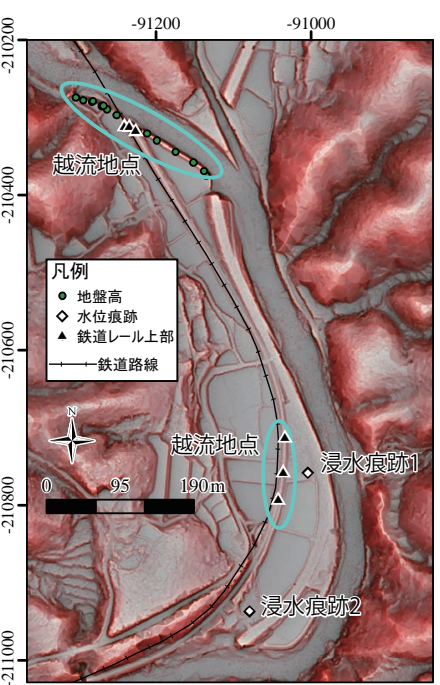

図-3 GPS 計測地点の配置図 $\mathrm{mm}$ ，美祢市秋吉台で $584.5 \mathrm{~mm}$ ，下関市豊田で $570 \mathrm{~mm}$ であり, 最大日降水量, 最大一時間降水量も記録的な 值を示した ${ }^{2)}$ が，山崎ら ${ }^{3)} に よ る$ 検証では最大三時間 降水量や日降水量の再現確率は 2.7 年から 27.7 年程度 と分析されている。このことから，先行降雨の影響と 15 日の時空間的な降雨パターンの複合的影響により大 きな被害をもたらしたものと考えられる3).

\section{(3) 被害の概要}

厚狭川流域下流に位置する山陽小野田市では，洪水 汇濫により床上・床下浸水合わせて 820 棟に達した ${ }^{1)}$.

路線が厚狭川に沿って配置された美祢線は, 複数の 鉄道橋の流失や各所での盛土やバラストの流失がみら れ 7 月 15 日から不通となった。鉄道再開のための予算 の一部を山口県が措置して, 翌年の平成 23 年 9 月に全 線での運転が再開された。

図-2に随光川合流点の直下流に位置する松ヶ瀬地区 の航空写真を示す。同地区は, 厚狭川流域の中流部の 下流側に位置する．河道は屈曲しており内岸側に位置 する低地は農地などに利用されている。 また，国道 316 号線や美祢線が河道に平行して配置されている。この 地区では河川からの汇濫により低地が冠水し, 美祢線 の盛土の大規模な流失が見られた。この地区では橋梁 の流失は見られなかったが, 流木等による通水断面の 減少が確認された。

\section{3. 松ヶ瀬地区周辺の地形情報の検証}

平成 24 年 2 月に当該地域を対象に, $1 \mathrm{~m}^{2}$ に 1 点の計 測密度で航空レーザー測量を実施した。計測されたデー タに基づき，計測值をグリッドに補間した DSM (Digital Surface Model) と, フィルタリング処理により地盤高を 抽出し，これを内挿した DEM (Digital Elevation Model) の 2 種類のデータが整備された.

出水前に実施された横断測量結果と, 出水後の実施 した航空レーザー測量により得られたデータを比較す
ると, 一部の斜面形状に相違がみられたものの, 基本的 に両者はよく一致していた. 斜面形状の相違について は主に計測時期の違いに起因し, 越流部を除き, 出水 時から航空レーザー測量実施時までに河道改修等は実 施されていないことから, 数值モデルにおいて基本的 に航空レーザー測量データに基づき標高分布を与える こととした。水面下については航空レーザー測量で取 得できないため, 横断測量結果と比較して, 航空レー ザー測量の標高が平坦で, かつ $20 \mathrm{~cm}$ 程度以上過大評 価されている点は, 水面反射を捉えていると判断し, 横 断測量データの值を最終的な標高值とした。

松ヶ瀬地区の上流側の越流地点には護岸および若干 の築堤が見られる。これらの標高は越流流量に大きな 影響を与えるが, 航空レーザー測量時には洪水越流地 点の護岸の補修工事が行われていた。越流地点の護岸 の形状把握, 堤防および鉄道の計測精度の検証, 痕跡 水位の実測のため, 平成 25 年 6 月 13 日に RTK-GPS 測 量を実施した。図-3に計測地点の配置を示す。

越流地点の堤防天端標高の GPS 計測值と航空レーザー 測量により作成された同地点での DEM および DSM 標 高を図-4に比較する．航空レーザー測量の值は, GPS 計測值と比較すると若干過大評価傾向があることが確 認できる. 植生被覆のある場合には, DSM 標高は実際 の地面より高い值となる傾向があるが，ここでは，一点 を除くと DSM 標高と DEM 標高はほぼ同じである．堤 防は草で覆われており，また定期的に刈り取りが行わ れることから, 比較的密度の高い草体で覆われる. その ため地表面までレーザー信号が到達しづらく, 結果と して, 平均すると DEM 標高は GPS 標高に比べて 0.13 $\mathrm{m}$ ほど過大評価したと考えられる.

図-5には鉄道盛土越流地点付近での, GPS により計 測したレール上面の標高と DEM，DSM 標高を比較す る. GPS 標高と比較して DSM 標高は $0.11 \mathrm{~m}$ の過小評 価, DEM 標高は $0.18 \mathrm{~m}$ の過小評価となっている.レー 


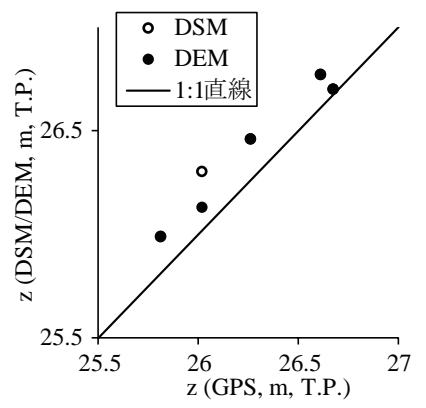

図-4 越流地点の堤防天端の GPS, DEM, DSM 標高の比較

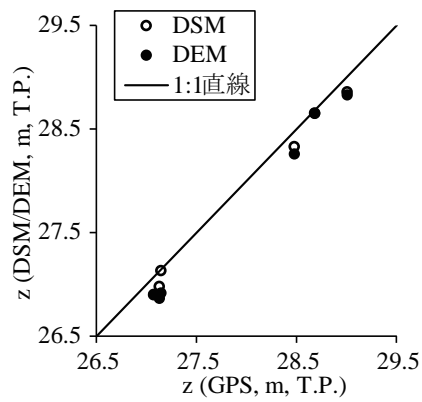

図-5 鉄道レール上面の GPS 標高と，その位置での DEM, DSM 標高の比較

ルの高さ (レール上面と枕木上面の高さの差) は $0.14 \mathrm{~m}$ から $0.16 \mathrm{~m}$ 程度である ${ }^{4)}$. DEM 標高は枕木高さに相 当する高さを捉えているものと考えられ, DEM 標高を $0.18 \mathrm{~m}$ 嵩上げしたものがレール上面高さに相当すると 判断できる.

以上の結果を踏まえ, 航空レーザー測量データを用 いて微地形を考慮した氾濫解析を実施する際の注意点 を考察する．氾濫解析を行う場合の標高值は，地表の 高さを表す DEM を用いる。植生や家屋の影響について は，一般的に粗度係数や抗力モデルにより評価できる. 家屋の形状を格子形状として与える場合には, 別途建 物のラスターデータを用意するか, レーザー計測結果 より構造物外形を算定することができる ${ }^{5)}$. 本研究で は, 解析地域の植生や家屋の密度が小さく, 洪水氾濫 流への影響は限定的であるため, 植生や家屋の効果は 簡易的な粗度係数による評価を行うこととした。

氾濫流の挙動に非常に大きな影響を及ぼす線状盛土 地形について, DEM 標高をそのまま用いると盛土高さ を過大評価し，また鉄道盛土の高さについてはDEM 值 は実際のレール上面より過小評価する傾向が認められ た。これらの差は, レーザー測量の精度の範囲である が, 少なくとも本研究の分析範囲において, ばらつき というよりは明確なトレンドとして確認された。また 氾濫水深の予測はサブメートルオーダーの精度が要求 されることから, これらの標高は補正することが望ま しい. 従って, 次章以降の氾濫解析において標高分布は DEM 值を用いて設定することとし, 河川堤防について は $0.13 \mathrm{~m}$ 引き下げ, 鉄道盛土については $0.18 \mathrm{~m}$ の嵪上
げを行う事とした。越流地点付近の鉄道橋による洪水 流のせき上げ効果についてはドビッソン (D'Aubuisson) 式により考慮した ${ }^{6)}$. ただし, 流木等による閉塞量に 関する定量的情報が入手できなかったため，橋梁によ る排除面積のみを対象にせき上げ効果を評価した。

\section{4. 松ヶ瀬地区の堤内地の盛土流失機構の分析}

\section{(1) 氾濫解析の計算条件}

分析対象の河道区間が約 $2 \mathrm{~km}$ と短く, 河床勾配も $1 / 240$ 程度と比較的急峻であることから，ピーク流況条 件での定常状態を再現することとした。 山口県により 算定された通過流量の分析結果に基づき，厚狭川から の流入量は $811 \mathrm{~m}^{3} / \mathrm{s}$, 随光川からの流入量は $110 \mathrm{~m}^{3} / \mathrm{s}$ と設定した。非構造格子を用いた 2 次元不定流モデル に一定流入流量を与えた。計算格子は盛土部分は $2 \mathrm{~m}$, それ以外の部分は $5 \mathrm{~m}$ の辺長の三角形格子を生成した. 粗度係数について河道・地面を 0.03 , 植生を 0.1 , 建物 を 0.1 とした. 河道の粗度係数は山口県による既往計画 等の際に利用された值と同一である.下流端水位は山 口県による洪水再現計算の水位分布をもとに設定した。

\section{（2）水位の再現性}

痕跡水位が確認された 2 地点 (図-3 を参照) での水位 と, 汇濫計算により算定された水位を比較する．氾監 計算の流入出条件は定常で与えたが, 氾濫域や水際で 渦などに起因する変動がみられ，完全な定常状態には ならなかった。 そのため, 再現性評価に用いる水位は 1 分おきの 20 分間の平均值と最大值の二通りを算出し た. 痕跡水位 1 は同地点にある工場の内壁に残った水 位痕であり, 実測值は $25.98 \mathrm{~m}$ であるのに対し, 計算水 位は平均 $25.79 \mathrm{~m}$, 最大 $25.90 \mathrm{~m}$ であった. 痕跡水位 2 については実測值は $25.81 \mathrm{~m}$, 計算結果は平均 $25.61 \mathrm{~m}$, 最大 $25.67 \mathrm{~m}$ であった。計算結果の水位は平均值で約 $19 \mathrm{~cm}$, 最大值で $11 \mathrm{~cm}$ 程度, 水位を過小評価している. 中山間地域では比較的地形起伏が大きく, 氾濫水の水 面勾配も大きいため, 汇監水位を精度良く評価するこ とが比較的困難である (例えば 2009 年の佐用川汇監の 解析では 20 地点での氾濫解析水位と水位痕跡との差は 平均で $28 \mathrm{~cm}$ 程度であった $\left.{ }^{6)}\right)$. このことから, 本研究 で評価された水位の精度は十分とは言えないが, 現状 の技術水準としては妥当な範囲と考えることができる.

\section{(3) 氾濫流況}

氾濫解析により再現した洪水氾濫流況を図-6に示す. 図-6a に示す白色破線は美祢線を，灰色実線は国道 316 号線を示している. 図-6bに示す標高分布より河道は基 本的に掘り込み型であり, 一部沿線に配置された道路 が微高地として堤防の役割を果たしていることが確認 できる. 図-6c に示す水位分布から, 河道左岸側の低平 地に河道内の水位と同程度の氾濫水が流れており, 氾 濫水が河道に併走して流れるいわゆる流下型の形態 7) 


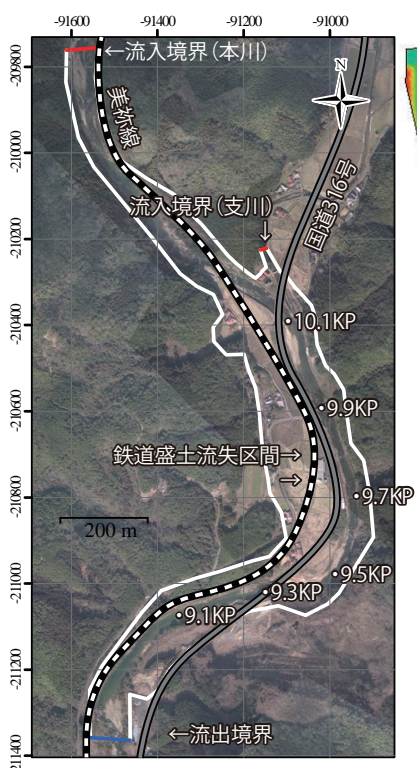

(a) 計算領域

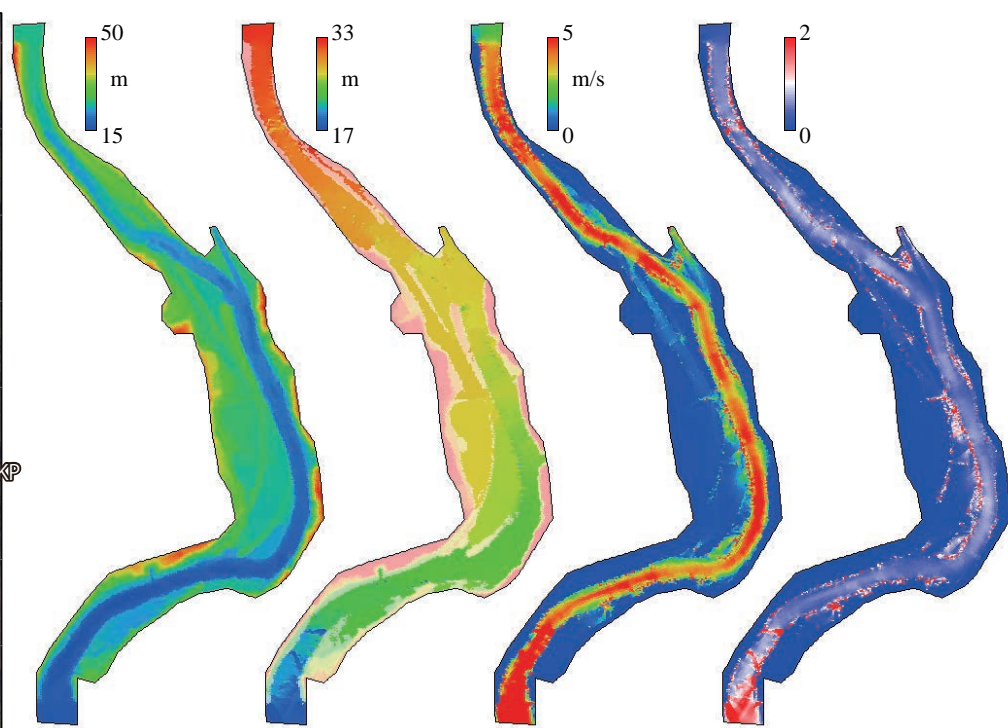

(b) 標高 (c) 水位 (d) 流速

図-6 計算領域と計算結果（水位 (c) の色の薄い部分は冠水していない部分を示す. 標高 (b) と水位 (c) はそれぞれが見やすい ようにカラーレンジを変えて示している.)
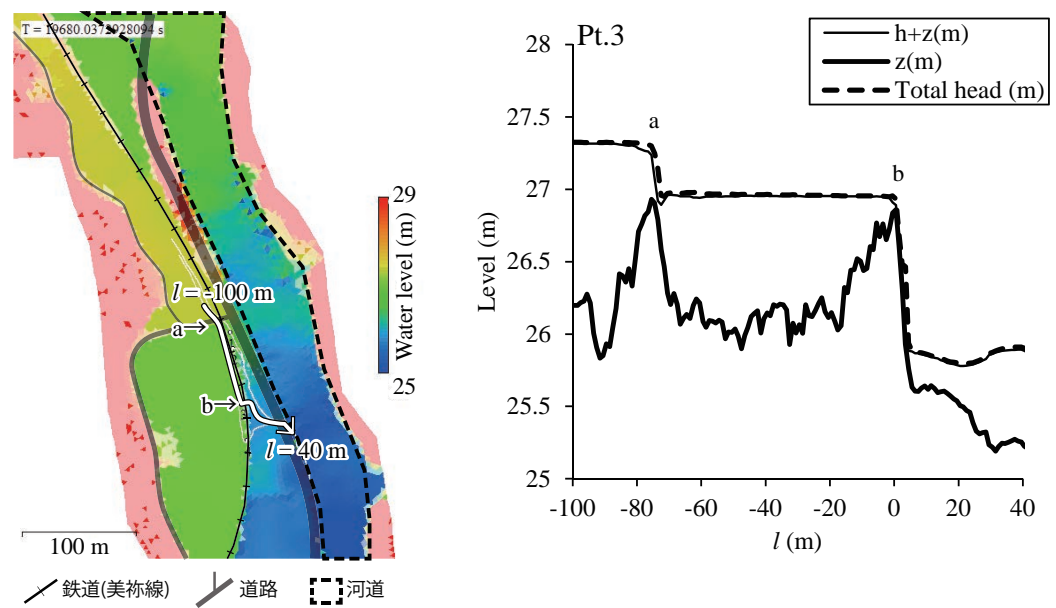

図-7 汇濫域の水位分布 (左) と鉄道盛土流失部を通る流線に沿った全水頭, ピエゾ水頭, 標高の分布（右）

であることがわかる．氾濫域の水位分布は，鉄道盛土お よび道路盛土により区画されて，段階的に水位が低下 しながら河道に氾濫水が戻っていることが確認できる. 図-6d に示した流速分布および図-6e に示したフルード 数分布より, 洪水汇濫流は河道を集中して流れており, 河道の一部で局所的に 1 前後の高いフルード数が発生 していることが確認できる.

氾濫域では上流の左岸側の斜面と鉄道に囲まれた低 平地を川に平行して氾濫水が流下している. それ以外 の氾濫域は，基本的に流速が小さく停滞しているが, 盛 土の越流部分で局所的な高速流が発生しており, 盛土 の上流側は氾濫水のせき上げが生じている。また鉄道 盛土の流失区間の下流側はフルード数が高く，限界流・ 射流が発生している.

図-7に，鉄道盛土流失部分の周囲の水位分布と，越 流する流れの流線に沿った全水頭, ピエゾ水頭, 標高
の分布を示す。左側に示した水位分布中の白実線は鉄 道盛土を越流した流れの流線であり, その流線に沿っ た水理量を右側のグラフに示している. 図-7 右のグラ フ中に a で示した起伏は道路盛土であり, 天端に対し て上流は $0.3 \mathrm{~m}$ 程度の標高差 (越流水深) が生じている. 同グラフ中の b 起伏は鉄道盛土であり，越流後に約 1 $\mathrm{m}$ の大きな水位差が生じているが越流水深は $0.12 \mathrm{~m}$ ほ どで, 直前の道路盛土越流部分に比べると小さい. 道 路盛土の上流部分に貯留された氾濫水は延長 $30 \mathrm{~m}$ 程度 の道路盛土区間を越流するが，その下流部の鉄道盛土 で貯留された氾濫水は, 鉄道盛土の $120 \mathrm{~m}$ 程度の区間 を分散して越流している. 鉄道盛土の越流幅が相対的 に大きいため, 鉄道盛土の越流水深は上流の道路盛土 の越流水深より小さくなっている.

氾濫流は河岸や堤内地の盛土の周囲に比べ低いとこ ろを集中して通過する。 また盛土が水平に近ければ広 


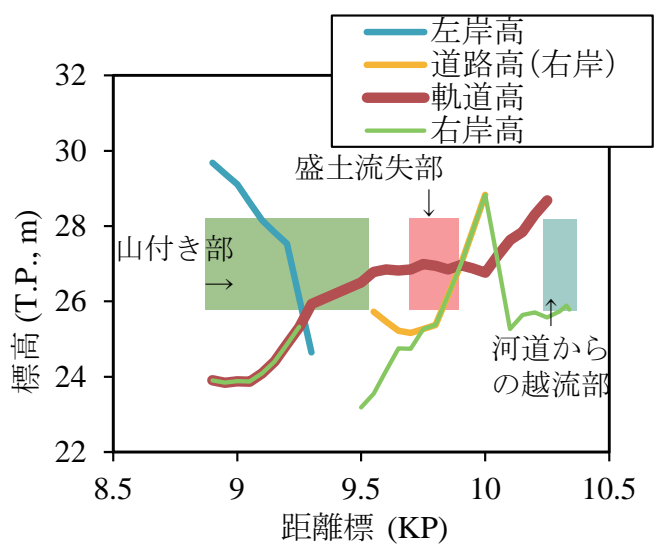

図-8 河岸 · 道路 · 鉄道の標高縦断分布

い範囲を分散して越流する，従って，河岸や盛土の縦 断分布から, 洪水汇濫が起きた際の汇濫流の挙動をあ る程度事前に予測できる可能性がある。そこで, 本事 例での河岸や盛土の縦断分布を図-8に示し, 標高の縦 断分布と汇濫流との関係を分析する. 横軸の距離標の 位置は図-2 の河道内の数字と対応している. 鉄道盛土 の流失部分は $9.7 \mathrm{KP}$ 付近であり, 軌道高は平坦になっ ている. 流失部分の上流側の $9.8 \mathrm{KP}$ から $10.0 \mathrm{KP}$ の区間 も, 軌道高は流失部分と同程度であるが, この部分の 軌道自体に大きな被害はなかった。これは, 9.8KPから $10.0 \mathrm{KP}$ の区間は, 右岸の道路は左岸につながる道路橋 の取り付け部の盛土であり, 軌道高より右岸の道路高 の方が高く, 氾濫域と河道が道路盛土により分割され てため, 鉄道盛土は浸水するが強い越流は生じなかっ たためである．9.5KP より下流側では右岸は山付き部 になっており, 浸水は起きていない.

\section{5. 考察}

\section{(1) 堤内地の盛土の越流と被害}

図-7 の右側に示した汇濫水の水位分布より, $\mathrm{b}$ 地点 の鉄道盛土部分より, 上流側の $\mathrm{a}$ 地点の道路盛土地点 は水位差が大きく単位幅辺りの越流流量は相対的にか なり大きい。ところが，道路盛土は一部の破損はみら れたものの残存した一方で, 鉄道は $120 \mathrm{~m}$ ほどの区間 でバラストや通信線の流失があり, その内の $80 \mathrm{~m}$ 程度 の区間では鉄道盛土の流失が確認された。その原因と して, 道路盛土と鉄道盛土の越流に対する耐久性の違 いが考えられる．すなわち，鉄道盛土においては天端 がバラストに覆われており, そのバラストは越流によ り流失しやすいのに対し ${ }^{4)}$, 道路盛土は天端がアスファ ルト舖装されており, 越流に対する耐久性があるため である。 その他の要因として, 道路盛土の越流部下流 は湛水しており水位が道路天端と同程度であったため, 盛土下流法面の侵食や越流後の落堀形成が抑制された と考えられる. 一方, 鉄道盛土は越流後の落差が大き く高速流が発生して下流側法面の侵食やバラスト流失
が促進されたものと考えられる。

図-8に示す鉄道盛土の標高分布 (軌道高) より, 鉄道 盛土流失区間の高さがほぼ水平な区間でバラスト流失 が起きたことがわかる．鉄道盛土が天端から浸食され ていくと, その浸食部分を集中して汇濫水が流れるよ うになる. 一方, 本事例では比較的広い範囲での流失 が見られたことから, 越流流れにより天端ではなく鉄 道盛土下流側の法面侵食が進んだことが広い範囲での 鉄道盛土の流失につながったものと考えられる.

\section{（2）氾濫流による被害の低減策}

当該地区において, このような氾濫流に起因する被 害が発生した地形要因としては, 谷底平野部の上流端で ある $10.3 \mathrm{KP}$ 付近の右岸の標高が低く, ここから越流・ 氾濫が起きたことがあげられる。この位置は, 汇濫域 の中では比較的標高が高いため, 一旦越流した汇濫水 は地形勾配により流下していくこととなる.よって上 流部分の護岸・堤防を補強して, 上流からの越流・汇濫 を抑制することが汇濫流を弱めることにつながる。 こ のような部分的な堤防の嵩上げは, 全体的な浸水が起 こることを防ぐわけではないが，氾濫流速を抑制する 効果が期待できる.

図-9に, 現状地形と氾濫域上流の越流部分を $2 \mathrm{~m}$ 嵩 上げした場合の汇濫流況を比較する. 図-9の上半分は水 位分布を, 下半分は Line Integral Convolution (LIC) 法 により可視化した ${ }^{6)}$ 流況を示す. パターンの方向は流 向を示し, 色の違いは単位幅流量に対応している. 水位 分布の比較より, 越流部分の嵩上げを行う事により氾 濫域の水位が低下していることが確認できる. 流況を 確認すると, 現状地形ケースの図中に A 地点で示した 位置から越流した洪水流が汇濫域を流下しており, その 一部は $\mathrm{C}$ 地点を通り逆流しながら $\mathrm{B}$ 地点で河道に戻っ ている. B 地点では河道の流れが上流部で越流し $\mathrm{C}$ を 逆流した流れとともに河道に再び合流している. $2 \mathrm{~m}$ 嵩 上げしたケースでは, A 地点からの越流は続いている が, 現状地形のケースに比べると汇濫流は弱くなってお り, また B 地点での複雑な流れも解消されている. 表-1 に, 図-9a 上に示した断面の $Q_{1}$ (河道断面), $Q_{2}$ (道路盛 土と鉄道盛土の間), $Q_{3}$ (鉄道盛土と後背山地の間) の各 部分の通過流量を比較する. 現状地形ケースでは $Q_{3}$ 地 点を流下した $46 \mathrm{~m}^{3} / \mathrm{s}$ の内 $10 \mathrm{~m}^{3} / \mathrm{s}$ は $Q_{2}$ 地点から河道 に戻っており, 氾濫域の下流へ流入する流量は $Q_{2}+Q_{3}$ の $36 \mathrm{~m}^{3} / \mathrm{s}$ である.これは河道を流れる流量に対しては $4 \%$ 程度である. $1 \mathrm{~m}$ 嵩上げしたケースでは, 汇濫域を 流下する流量は $28 \mathrm{~m}^{3} / \mathrm{s}$ と半減しており, $2 \mathrm{~m}$ 嵩上げし たケースではさらに減り $2 \mathrm{~m}^{3} / \mathrm{s}$ と評価されている.こ のように上流越流地点の嵪上げは, 松ヶ瀬地区の汇濫 流量を抑制する効果が大きく, 氾濫流に起因する下流 の被害を抑制する効果が高い. 汇濫域への流入流量は, 越流地点に形成された支配断面により規定されるため, 氾濫域の内部の盛土や下流側の河川への還流部分の盛 土の嵪上げや築堤は, 氾濫域への流入流量の制御につ 


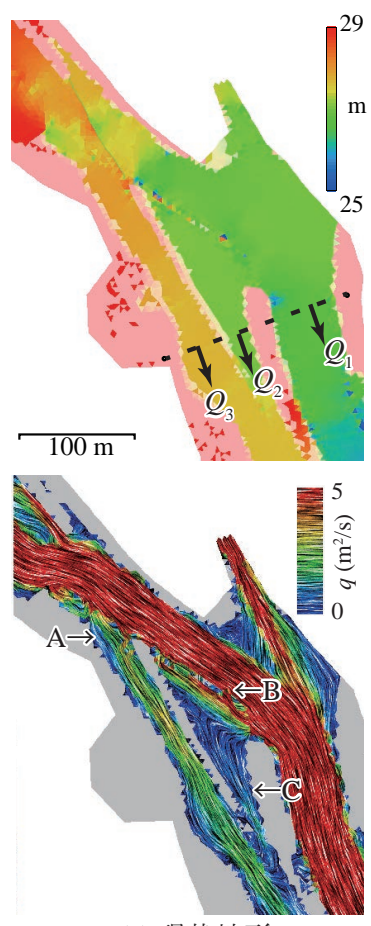

(a) 現状地形
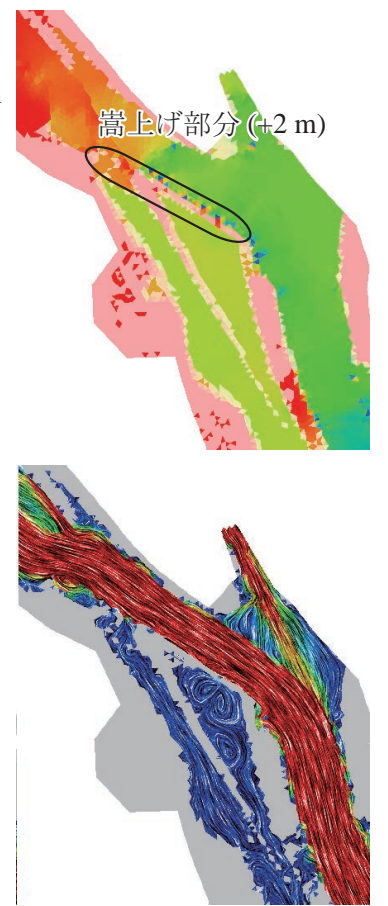

(b) 越流部嵩上げ $+2 \mathrm{~m}$
図-9 氾濫域上流の越流部分の堤防嵩上げの検討 (上段 : 水位 分布, 下段：LIC 法による流況可視化）

表-1 各断面の通過流量の比較

\begin{tabular}{|c|c|c|c|}
\hline ケース名 & $Q_{1}$ & $Q_{2}$ & $Q_{3}$ \\
\hline 現状地形 & 893 & -10 & 46 \\
\hline 越流部嵩上げ+1m & 914 & -9 & 37 \\
\hline 越流部嵩上げ+2m & 931 & -6 & 8 \\
\hline 現状地形 (橋梁なし) & 919 & -3 & 12 \\
\hline
\end{tabular}

ながらない，むしろ，これらの盛土や築堤部の上流側 に汇濫水が湛水することから, 盛土等を嵩上げするこ とは，上流側の浸水深を大きくする効果があり，実施 すべきではない，特に氾濫域内の鉄道などの盛土を高 くすることは，十分な排水経路が確保されている場合 を除き，むしろ盛土前後の水位差を大きくし盛土の流 失リスクを増大させることになる.

越流部の周辺に架かる鉄道橋のせき上げ効果を評価 しない条件での通過流量の解析結果を表-1 の最下段に 示している. せき上げを考慮した現状地形の結果と比 較して, 汇濫流量が減少している。当該地区への汇濫 流による被害を軽減させる上で，鉄道橋梁をせき上げ を防ぐ形へ改修することも効果的である.

\section{6. おわりに}

平成 22 年 7 月に発生した梅雨前線による降雨で生じ た山口県美袮市松ヶ瀬地区の洪水氾濫と鉄道盛土流失 の被害状況を分析した。航空レーザー測量により得ら

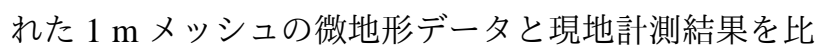
較したところ，小規模の堤防や鉄道盛土では標高のバ イアスが確認された。これらの結果を踏まえ, 松ヶ瀬 地区の氾濫水の流れを再現した。 その結果, 松ヶ瀬地 区上流右岸側から越流した流れが，河道や河道に併走 する道路・鉄道に沿って流下して，道路盛土や鉄道盛 土によってせき止められた汇濫水がそれぞれの盛土を 越流して河道に戻ったことが確認された，鉄道盛土の 越流は $120 \mathrm{~m}$ 程度の区間を分散して越流し, 越流後の 落差が大きいことも影響して法面侵食に起因した大規 模な盛土流失が起きたものと推察された。このような 氾濫流に起因する交通網などへの被害を軽減させるた めには, 氾濫域の上流部分から越流を抑制することが 有効であり, その施策としては越流部の部分的嵩上げ, および橋梁改修による洪水流のせき上げ量の低減が有 効と考えられる. 汇濫域の面積が限定されているため, これらの施策を実施したとしても下流への洪水伝搬速 度や流量への影響は極めて限定的である.

謝辞 : 河道や水文データなどの情報を山口県土木建築 部河川課よりご提供いただきました。航空レーザー測 量の実施につきまして, アジア航測株式会社・阪口和之 氏にご協力をいただきました。水位痕跡について, 菊 永工業株式会社および阿部氏にご協力いただきました. 本研究の一部は, 中国建設弘済会より助成を受けて行 われました。ここに記し謝意を表します。

\section{参考文献}

1）永野博之, 羽田野袈浆義, 銭谷淳, 朝位孝二, 赤松良久: 2010 年 7 月の豪雨による厚狭川流域で発生した水害の特性に ついて, 第 66 回年次学術講演会講演概要集, pp. 335-336, 2011.

2) 山口県: 災害記録～平成 22 年 7 月 15 日大雨災害～, 山口 県総務部防災危機管理課, 2010.

3) 山崎俊成, 山本晴彦, 立石欣也, 原田陽子, 高山成, 吉越恆, 岩谷潔: 2010 年 7 月 15 日に山口県において発生した豪雨 の特幑と水災害の概要, 自然災害科学, Vol. 3, No. 29, pp. 413-425, 2010.

4) 上田康弘, 椿涼太, 河原能久, 吉田浩紀: 鉄道盛土の越水に よる上部構造の流失機構・条件の解明, 河川技術論文集, Vol. 18, pp. 375-380, 2012.

5) 椿涼太, 藤田一郎, 岡部健士: 航空レーザー測量を用いた 高解像度非構造格子の自動生成と汇濫解析, 土木学会論文 集, Vol. 810/II-74, pp. 91-102, 2006.

6) T. Tsubaki, Y. Kawahara, T. Sayama, and I. Fujita: Analysis of geomorphic and hydraulic conditions causing railway embankment breach due to inundation flow, Journal of $\mathrm{Hy}$ droscience and Hydraulic Engineering, Vol. 30, No. 1, pp. 87-99, 2012.

7) 国土交通省: 中小河川浸水想定区域図作成の手引き, 河川 局治水課, 2005.

(2013.9.30 受付) 